\title{
The International Council of Scientific Unions
}

$\mathrm{T}^{\mathrm{T}}$ HE International Council of Scientific Unions, formerly the International Research Council, will meet at the rooms of the Royal Society, for the first time in Great Britain, on April 26. The original statutes laid down that the triennial meetings of the Council should be held at Brussels, but these were altered in 1931 to empower the General Assembly to accept invitations from other countries.

The present Council was established in 1919 after its predecessor, the International Association of Academies, had lapsed during the Great War after actively promoting international science for about sixteen years.

For some years before 1898, the Academies of Munich and Vienna, with the Royal Societies of Göttingen and Leipzig, had been in the habit of meeting annually at one or other of these places as an association to discuss matters of common interest, and in 1898 they were to meet at Göttingen. The Royal Society of Göttingen invited the Royal Society to send delegates to take part in the meeting and its discussions, and also intimated that the four institutions would be glad to learn the views of the Royal Society on the possibility and desirability of its joining them. The Council of the Royal Society accepted the invitation and instructed its delegates to say that the Society would be disposed to join the association provided that it were so extended as to assume a fully international character. The suggestion was accepted in principle, and the Royal Society was requested to take such steps as might be desirable to ascertain how far the formation of such an international association might commend itself to the leading scientific bodies of other countries. As a private institution, the Royal Society was very favourably situated for opening such negotiations.

In the following year the Académie des Sciences of Paris, the Academia dei Lincei of Rome, the Imperial Academy of Sciences at St. Petersburg, and the National Academy of Sciences at Washington, approved of the proposal and expressed their readiness to join such an international association. A preliminary conference was therefore held at Weisbaden in October 1899, at which a draft scheme for the organization was prepared providing for triennial meetings of the General Assembly, which would consist of delegates from each adhering Academy. The Assembly was to be formed of two sections, one for the natural sciences, and the other for literature and philo. sophy. The Council of the Association held its first meeting at Paris in 1900.

By the organization of the association an academy might be admitted either to the literary section alone, or to the scientific section alone, but not to both unless its constitution showed that the sphere of its labours included both literary and scientific subjects; and as at that time there was no society in existence in England dealing with the subjects of the literary section in such a manner as to satisfy these conditions, the United Kingdom could only be represented in the scientific section by the Royal Society. The Council, therefore, consulted several distinguished men of letters, a number of whom afterwards submitted a memorandum in which it was suggested that the Royal Society might either enlarge its scope so as to include a section corresponding to the philosophical, historical and philological division of some foreign academies; or that it might address a memorial to the Government pointing out the exceptional position in which Great Britain was placed as compared with other European countries through the absence of any academy representing departments of study other than mathematics and natural sciences, and advocating the formation of such an academy.

In 1900 the Council of the Royal Society appointed a committee of fellows of the Society to consider this memorandum and to report. The committee went into the whole matter very thoroughly and, after conferring with a number of representatives of historical and philological studies, presented a report, which was laid before a special meeting of the fellows, at which a very full and interesting discussion of it took place on May 9, 1901. The report came before the Council again at its meeting in July, and after full consideration it was resolved "that the Council while sympathising with the desire to secure corporate organisation for the exact literary studies considered in the Report, is of the opinion that it is undesirable that the Royal Society should itself initiate the establishment of a British Academy".

At the end of 1901 a number of those who had taken part in these discussions formed a new body, the British Academy for the Promotion of Historical, Philosophical and Philological Studies. This body drew up a petition to His Majesty in Council for the grant of a Royal Charter, and in 1902 the British Academy for the Promotion of Historical, Philosophical and Philological Studies was constituted, and incorporated by Royal Charters. 
During the Great War, the periodical meetings of the International Association of Academies and of many other international organizations could not be held, though some of them were continued in neutral countries. In 1918, therefore, the Royal Society, the Academy of Sciences, Paris, and the National Academy of Sciences, Washington, discussed informally the question of the future organization of the scientific undertakings which had been carried on before the War by international co-operation; and ultimately the academies of all the allied countries were invited to send representatives to a conference which took place at the rooms of the Royal Society in October 1918. This was followed by a meeting at Paris at the end of November, when it was agreed to form an International Research Council and a number of affiliated International Unions to deal with matters of international scientific interest, which was done at Brussels in the next year.

Besides the ordinary routine of the triennial meeting, which is being held in London on April 26May 4, the Council will have for consideration the report of the standing committee on the Study of Solar and Terrestrial Phenomena, and also that of the committee which was appointed three years ago to report on the relations which should exist between the Council and the Committee of Intellectual Co-operation of the League of Nations concerning matters of international science.
The Royal Academy of Amsterdam is proposing that the International Council should appoint a committee to study what co-ordination can be achieved in the opinions which have been put forward regarding the social responsibilities of science and of scientific workers towards the dangers at present menacing the future of civilization.

Public lectures will be given on April 28 and April 30 at the Royal Institution; the former by Sir William Bragg, on "Classical Experiments made at the Royal Institution", and the latter by Prof. E. V. Appleton, on "International Cooperation in Radio Research". The Government is giving an evening reception to the delegates at Lancaster House on April 29.

Arrangements have been made for the delegates to visit a large number of scientific institutions in and near London, where they will receive assistance from members of the scientific staffs in the objects of their visits.

The General Assembly will hold its closing meet. ing on Monday, May 3, and the delegates will attend the soirée of the Royal Society on Tuesday, May 4.

On Tuesday, April 27, there will be a reception of the delegates at the University of London, when the Chancellor of the University, the Earl of Athlone, will confer the honorary doctorate of science on Dr. N. E. Nörlund, the president of the International Council.

\section{The Total Solar Eclipse of June 1937}

$\mathrm{T}$ HE total eclipse which starts on June 9 next and, crossing the date line, ends on June 8, will be the longest visible for many years, the maximum duration of totality being 7 minutes 4 seconds. It is most unfortunate that the belt of totality lies almost entirely over the ocean and that the maximum duration available from land is reduced to 4 minutes 8 seconds. This is from Enderbury Island in the Phoenix Group (lat. $3^{\circ} 8 \cdot 5^{\prime} \mathrm{S}$., long. $171^{\circ} 10 \cdot 0^{\prime} \mathrm{W}$.) which is described in the Sailing Directions, Pacific Islands Pilot, vol. 2, 1932, as " 30 feet high, uninhabited and surrounded by a coral reef, which is steep to. There is no fresh water, no anchorage and landing is difficult". The island is about 2.5 miles long and 1 mile wide. Of the other islands in the Phoenix Group, which lie within the belt of totality - Gardner, McKean, Hall, Birnie, Canton and Phoenix, all uninhabited - the most suitable island for landing eclipse apparatus appears to be Canton Island (lat. $2^{\circ} 28 \cdot 9^{\prime}$ S., long. $171^{\circ} 42 \cdot 6^{\prime}$ W.).
Here totality lasts 3 minutes 45 seconds. The island is a coral atoll 10-12 feet high, with a spacious lagoon : there is anchorage, in 10 fathoms, unsafe with westerly winds, close to an entrance to the lagoon on the west side. Coco-nuts have been planted on the island, which is nine miles long by four miles wide. The islands are leased by the Colonial Office to Messrs. Burns Philp (South Seas) Co. Ltd., and come under the jurisdiction of H.E. the High Commissioner for the Western Pacific at Suva, Fiji.

The belt of totality east of the Phoenix group never strikes land until at sunset it reaches the coast of Peru. The U.S. Navy reported an island, Sarah Anne Island, which would have lain in the track of the shadow, but the island must have sunk below the ocean as it is no longer to be found. In Peru the maximum altitude of the sun is $8^{\circ}$ and the maximum duration of totality 3 minutes 20 seconds. The Faculty of Science of the University of San Marcos has formed a 